\title{
KOMUNITAS
}

Jurnal Pengembangan Masyarakat islam

Vol. 10, No. 1, Juni 2019

\section{SISTEM PATRIARKI DAN KEKERASAN ATAS PEREMPUAN}

\author{
Riska Mutiah \\ Fakultas Dakwah dan IImu Komunikasi UIN Mataram \\ Email: riskamutiah@uinmataram.ac.id
}

\begin{abstract}
:
Tatanan patriarki merupakan sebuah sistem sosial yang menempatkan laki-laki sebagai sosok otoritas utama yang sentral dalam organisasi sosial. Tatanan patriarki inilah yang menyebabkan perempuan menjadi subordinasi, termarginalkan, bahkan memperoleh ketidakadilan di dalam masyarakat. Tatanan patriarki mengabsahkan superioritas laki-laki dan inferioritas perempuan yang tidak hanya kita temui pada satu atau dua kelompok masyarakat namun dapat kita temui di seluruh belahan dunia dengan kasus yang paling parah terdapat pada negara-negara dunia ketiga, dimana Indonesia adalah salah satunya. Sampai hari ini catatan Komisi Nasional Anti Kekerasan Terhadap Perempuan menyebutkan setiap 2 jam sekali terdapat 3 perempuan Indonesia yang mengalami kekerasan seksual dan 60\% kasus kekerasan seksual terhadap perempuan terjadi di dalam ranah domestik korban. Bagi Luce Irigaray seksualitas dan hasrat laki-laki dalam bentuk alat kelamin adalah prinsip pengaturan tatanan simbolik dan melalui hal tersebut kuasa sosial dijalankan. Wacana-wacana universal, apakah itu filsafat, ilmu, atau kesusastraan semuanya diseksualisasikan dalam wacana maskulin. Jelas bagi Irigaray, nilainilai pencerahan (renaisans) tidak berlaku bagi perempuan. Karena hal tersebut, posisi sosial perempuan hari ini masih termaginalkan, tidak dianggap sebagai subjek melainkan sebagai objek seksual. Perempuan harus paham mengenai kondisi ini, agar tidak terus-menerus berada di dalam kekuasaan dominasi maskulin, setidak-tidaknya perempuan harus berusaha untuk keluar dari konstruk sosial yang telah dilekatkan tersebut. Yang perlu kita sadari bahwa membalikkan tatanan keseimbangan kekuasaan maskulin adalah mustahil jika tidak dilakukan secara bersama-sama oleh laki-laki dan perempuan, karena sistem patriarki telah menancapkan kukunya begitu dalam pada tatanan sosial kita.
\end{abstract}

Kata kunci: Sistem patriarki, Kekerasan Seksual, Tatanan Sosial.

\section{A. Pendahuluan}

Tatanan patriarki menyebabkan perempuan menjadi subordinasi, termarginalkan, bahkan memperoleh ketidakadilan di dalam masyarakat. 

Posisi maupun peran sosial tidak lepas dari pengaruh identitas gender yang dimiliki seseorang, laki-laki dan perempuan akan mendapat perbedaan peran maupun posisi sosial yang ada di dalam masyarakat. Perbedaan jenis kelamin dapat kita lihat dalam dua perspektif berbeda yaitu perspektif biologis (sex) dan perspektif sosial (gender) dimana terdapat perbedaan yang signifikan antara perspektif biologis dan perspektif sosial. Dari perspektif biologis, jenis kelamin laki-laki maupun perempuan adalah bersifat kodrati, tidak dapat dirubah dan berlaku selamanya, namun jika dilihat dari perspektif sosial, gender dikonstruk oleh struktur sosial budaya masyarakat, sehingga bisa dipertukarkan sesuai dengan masing-masing budaya yang berarti bahwa konstruksi gender merupakan kesepakatan sosial.

Tatanan patriarki mengabsahkan superioritas laki-laki dan inferioritas perempuan yang tidak hanya kita temui pada satu atau dua kelompok masyarakat namun dapat kita temui di seluruh belahan dunia dengan kasus yang paling parah terdapat pada negara-negara dunia ketiga, dimana Indonesia adalah salah satunya. Sampai hari ini cacatan Komisi Nasional Anti Kekerasan Terhadap Perempuan menyebutkan setiap 2 jam sekali terdapat 3 perempuan Indonesia yang mengalami kekerasan seksual. Maryana Amiruddin dari Komnas Perempuan menyebutkan bahwa 60\% kasus kekerasan seksual terhadap perempuan terjadi di dalam ranah domestik korban, seperti rumah dengan pelaku ayah, paman, kakak, hingga suami korban. Pada 2014 lalu, dari 3.860 kasus kekerasan pada perempuan di ranah komunitas, sebanyak 2.183 
E-ISSN: $2540-9182$

P-ISSN: 2086-3357

kasus atau 56\%-nya adalah kasus kekerasan seksual berupa perkosaan, pencabulan, pelecehan seksual dan paksaan berhubungan badan ${ }^{1}$.

Selain itu, terdapat kasus kekerasan terhadap perempuan yang saat ini harus mendapatkan perhatian khusus yaitu kekerasan seksual yang dilakukan oleh pacar. Kekerasan ini disebut dengan istilah dating violence atau black dating. Kekerasan ini tentunya menjadi fenomena gunung es. Psikolog keluarga Roslina Verauli mengatakan bahwa perilaku kekerasan sering menjadi pemakluman bagi korban, karena yang melakukan adalah orang yang dicintai, sehingga korban black dating tidak melaporkan kejahatan yang terjadi terhadap mereka, tindakan yang termasuk kategori kekerasan dalam berpacaran meliputi pemaksaan dalam melakukan atau tidak melakukan sesuatu. Contoh paling sering adalah paksaan melakukan hubungan seksual dan menyentuh bagian tubuh tertentu yang tidak diinginkan pasangan. "Biasanya paksaan berupa dicium tapi tidak ingin dicium, atau paksaan untuk diraba-raba padahal tidak ingin diraba-raba," ujar Roslina². Kekerasan secara fisik maupun verbal yang dilakukan oleh laki-laki terhadap pasangan perempuannya juga sering tejadi. Hal ini terjadi karena laki-laki merasa superior terhadap perempuan, sementara perempuan juga menganggap bahwa dirinya lemah dan tidak mampu melakukan perlawanan.

\footnotetext{
${ }^{1}$ BBC Indonesia, Kekerasan Seksual pada Perempuan dan Inferioritas Laki-laki. Diakses dalam http://www.bbc.com/indonesia/berita indonesia/2015/11/151125 indonesia kekerasan seksual_i nferioritas (27/11/2015, $14.17 \mathrm{WIB})$.

${ }^{2}$ Tempo.co, Korban Kekerasan Pacar seperti Fenomena Gunung Es. Diakses dalam http://gaya.tempo.co/read/news/2015/01/18/205635613/korban-kekerasan-pacar-sepertifenomena-gunung-es $(27 / 11 / 2015,13.50 \mathrm{WIB})$.
} 
Riska Mutiah

\section{B. Kerangka Teori}

Pemikiran-pemikiran Luce Irigaray dipengaruhi oleh banyak tokoh seperti Sigmund Freud, Jacques Lacan, Jacques Derrida, Maurice Marleau-Ponty, Martin Heiddeger, serta Emmanuel Levinas. la banyak dipengaruhi oleh Freud dan Lacan namun teori-teori para pemikir tersebut digunakan untuk dikiritisi kembali.

\section{Kritik Terhadap Tatanan Patriarki}

Pemikiran utama Irigaray adalah membebaskan yang feminin dari filsafat maskulin. la mencatat bahwa segala sesuatu yang kita ketahui tentang perempuan termasuk hasrat seksualnya adalah didapat dari sudut pandang laki-laki. Satu-satunya jenis perempuan yang kita kenal adalah perempuan yang maskulin, perempuan yang sebagaimana dilihat oleh laki-laki. Bagi Irigaray, ada jenis perempuan lain yang juga harus dikenali yakni perempuan feminin, perempuan yang sebagaimana dilihat oleh perempuan itu sendiri. la memandang hidup perempuan dalam ranah imajiner sebagai penuh dengan kemungkinan yang sama sekali belum tersentuh oleh perempuan. Wacana maskulin tidak pernah berhasil memahami perempuan atau yang feminin, sebagai sesuatu selain daripada refleksi laki-laki atau yang maskulin ${ }^{3}$. Irigaray bergerak melampaui pemikiran Lacan tentang tatanan patriarki phallosentris dengan pandangannya bahwa ke-yang-lain-an seksualitas perempuan telah direpresi oleh patriarki yang mencoba menteorisasikannya ke

${ }^{3}$ Rosemarie Putnam Tong, Feminist Thought: Pengantar Paling Komprehensif kepada Arus Utama Pemikiran Feminis (terjemahan Aquarini Priyatna Prabasmoro), Yogyakarta: jalasutra, 2010. 
E-ISSN: $2540-9182$

P-ISSN: 2086-3357

dalam parameter maskulin. Definisi patriarki tentang seksualitas menyebabkan perempuan kehilangan sentuhannya terhadap feminitas es ensialnya yang terletak di dalam tubuh perempuan, dengan kapasitasnya untuk memperoleh kenikmatan yang berulang dan heterogen ${ }^{4}$.

Irigaray juga mengkritisi teori Freud atas seksualitas perempuan, dimana Freud memandang anak perempuan sebagai defisiensi atau negatifitas, atau sebagai laki-laki kecil tanpa penis. Freud menekankan gagasan mengenai perbedaan dengan mengkarakterisasi perempuan sebagai kekurangan. Perempuan adalah refleksi dari laki-laki, sama dengan laki-laki kecuali dalam seksualitasnya. Seksualitas perempuan, karena tidak mencerminkan seksualitas laki-laki adalah suatu kealpaan ${ }^{5}$. Feminin ditentukan sebagai tidak ada apapun selain pelengkap, sisi lain atau sisi negatif dari maskulin. Dalam analisisnya, Irigaray tidak tertarik pada anatomi melainkan pada morfologinya atau dengan kata lain dalam cara hal tersebut direpresentasikan dan dikonseptualisasikan sebagai wacana maskulin. Seksualitas dan hasrat laki-laki dalam bentuk alat kelamin adalah prinsip pengaturan tatanan simbolik dan melalui hal tersebut kuasa sosial dijalankan (Brooks, 2011). Wacana-wacana universal, apakah itu filsafat, ilmu, atau kesusastraan semuanya diseksualisasikan dalam wacana maskulin. Jelas bagi Irigaray, nilai-nilai pencerahan (renaisans) tidak berlaku bagi perempuan ${ }^{6}$.

\footnotetext{
4 Ann Brooks, Posfeminisme dan Cultural Studies: Sebuah Pengantar Paling Komprehensif (terjemahan S. Kunto Adi Wibowo), Yogyakarta: Jalasutra, 2011, 118.

${ }^{5}$ Op. cit, hal. 297.

${ }^{6}$ Sarup Madan, Panduan Pengantar Untuk MEmahami Poststrukturalisme dan Postmodernisme (terjemahan Medhy Aginta Hidayat), Yogyakarta: Jalasutra, 2011, 182.
} 
Satu-satunya cara mengubah status perempuan secara fundamental adalah melakukan definisi yang menegaskan arti feminin yang sebenarnya atau menciptakan pengertian simbolik perempuan yang kuat. Persoalan utama yang harus diperhatikan adalah mendefinisi dengan cara apapun akan menciptakan kembali feminin yang falik. Feminin yang dapat diekpresikan dalam bentuk suatu konsep adalah membiarkan perempuan untuk terjebak kembali dalam sistem representasi maskulin. Irigaray tidak memiliki banyak waktu untuk membalikkan tatanan segala sesuatu, ia hanya membalikkan tatanan keseimbangan kekuasaan antara laki-laki dan perempuan. Perhatiannya tertuju untuk memajukan dan mendorong perkembangan bentuk-bentuk tatanan sosial yang spesifik bagi perempuan. la percaya bahwa entrefemmes merupakan syarat penting bagi penciptaan identitas dan subjektifitas perempuan di arena kultural. la menekankan perempuansebagai-subjek; ia mengatakan bahwa menempati posisi subjek lebih dari sekadar persoalan posisi pengucapan, tapi juga harus berakar pada praktik sosial. Perempuan harus ikut terlibat dalam proses penciptaan realitas kultural dan politik ${ }^{7}$.

2. Rumah Bahasa Bagi Perempuan

Salah satu tesis utama Irigaray adalah bahwa bahasa dan sistem representasi yang ada tidak dapat mengekspresikan hasrat perempuan. Laki-laki memiliki kemampuan metabahasa (bahasa yang berbicara tentang bahasa) dan perempuan tidak memilikinya. la mengatakan bahwa perempuan tidak bisa mengekspresikan diri melalui bahasa yang

\footnotetext{
${ }^{7}$ Ibid.
} 
E-ISSN: $2540-9182$

P-ISSN: 2086-3357

dibebankan kepada mereka saat memasuki tatanan simbolik ${ }^{8}$. Perempuan membutuhkan bahasa mereka sendiri. Laki-laki selalu mencari dan membangun rumah bagi mereka sendiri; gua, pondok, kota, teori, konsep, bahasa, bahkan perempuan, maka demikian juga perempuan membutuhkan rumah bahasa. Mereka membutuhkan rumah tinggal yang tidak memenjarakan mereka, sebagai ganti penjara yang tak tampak yang menempatkan mereka sebagai tawanan; tempat tinggal yang memungkinkan mereka tumbuh kembang adalah prasyarat bagi mereka untuk menjadi. Irigaray membuat pembedaan yang vital antara bicara seperti perempuan dan bicara sebagai perempuan, karena bicara sebagai perempuan menyiratkan tidak hanya pemposisian psikologis tetapi juga sosial ${ }^{9}$.

Sering dikatakan bahwa bicara atau menulis seperti laki-laki menegaskan penguasaan, mengontrol makna, mengklaim kebenaran, objektifitas, atau pengetahuan, sementara bicara sebagai perempuan berarti menolak penguasaan, membuat makna menjadi sulit dipahami atau berubah-ubah, tidak mengontrol, atau menguasai kebenaran, atau pengetahuan. Dengan kata lain, menjadi asertif, mengklaim, menjadi "dogmatis", yang berarti memiliki tesis, makna, posisi politis, adalah mengambil posisi laki-laki. Irigaray menekankan posisi subjek perempuan, ia mengatakan bahwa menempati posisi subjek lebih dari sekadar persoalan posisi pengucapan, tetapi juga harus berakar pada praktik sosial. Salah satu aspek definisi perempuan sebagai subjek ini adalah

\footnotetext{
${ }^{8}$ Ann Brooks, Posfeminisme dan Cultural Studies: Sebuah Pengantar Paling Komprehensif (terjemahan S. Kunto Adi Wibowo), Yogyakarta: Jalasutra, 2011, 117.

${ }^{9}$ Op. cit, hal 188.
} 
bahwa perempuan harus ikut terlibat dalam proses penciptaan realitas kultural dan politik ${ }^{10}$.

\section{Pembahasan}

Dalam melakukan kritiknya terhadap tatanan patriarki, Irigaray mempunyai pemikiran utama yakni membebaskan yang feminin dari wacana maskulin. Menurutnya, perempuan yang kita ketahui hari ini adalah definisi perempuan yang diciptakan dalam tatanan patriarki yang berarti bahwa perempuan yang sebagaimana dilihat oleh laki-laki. Hal ini sangat merugikan perempuan karena tatanan patriarki merupakan legitimasi superioritas laki-laki atas perempuan. Seksualitas dan hasrat laki-laki dalam bentuk alat kelamin adalah prinsip pengaturan tatanan simbolik dan melalui hal tersebut kuasa sosial dijalankan. Karena hal tersebut, posisi sosial perempuan hari ini masih termaginalkan, tidak dianggap sebagai subjek melainkan sebagai objek seksual. Seperti yang diterangkan sebelumnya bahwa kasus kekerasan perempuan yang dilakukan oleh laki-laki saat ini adalah semakin meningkat dari tahun ke tahun.

Gender dikonstruk oleh struktur sosial budaya masyarakat, sehingga bisa dipertukarkan sesuai dengan masing-masing budaya yang berarti bahwa konstruksi gender merupakan kesepakatan sosial, berikut adalah stereotip gender yang berlaku umum dalam masyarakat:

\footnotetext{
${ }^{10}$ Op. cit, hal 189.
} 


\begin{tabular}{|c|c|}
\hline Feminin & Maskulin \\
\hline Tidak agresif & Agresif \\
\hline Tidak independen & Independen \\
\hline Mudah terpengaruh & Tidak mudah terpengaruh \\
\hline Submasif & Dominan/berkuasa \\
\hline Pasif & Aktif \\
\hline Orientasi domestik & Orientasi publik \\
\hline Mudah terluka secara emosional & Tidak mudah terluka secara \\
\hline Bimbang & emosional \\
\hline Banyak bicara & Tegas \\
\hline Lemah lembut & Tidak banyak bicara \\
\hline Sensitif terhadap perasaan orang & Keras \\
\hline lain & Kurang sensitif terhadap perasaan \\
\hline Banyak menangis & orang \\
\hline Emosional & Jarang menangis \\
\hline Mengedepankan verbal & Logis \\
\hline Baik hati & Analistik \\
\hline Bijaksana & Kejam \\
\hline \multirow[t]{2}{*}{ Mengasuh anak } & Tanpa basa-basi \\
\hline & Tidak mengasuh anak \\
\hline
\end{tabular}

(Sumber: Akun Instagram Girltalkgroup)

Dapat kita lihat dari gambar di atas, perbedaan stereotip gender yang melekat pada sosok maskulin dengan feminin sangatlah jauh berbeda. Sifat-sifat yang selama ini dianggap unggul oleh masyarakat semuanya melekat pada sosok maskulin, sementara sifat-sifat yang dianggap lemah 
dilekatkan pada sosok feminin. Inilah yang dikritik oleh Irigaray dimana Freud memandang anak perempuan sebagai defisiensi atau negatifitas, atau sebagai laki-laki kecil tanpa penis. Freud menekankan gagasan mengenai perbedaan dengan mengkarakterisasi perempuan sebagai kekurangan. Seksualitas perempuan, karena tidak mencerminkan seksualitas laki-laki adalah suatu kealpaan. Feminin ditentukan sebagai tidak ada apapun selain pelengkap, sisi lain atau sisi negatif dari maskulin.

Konsentrasi Irigaray adalah membalikkan tatanan kekuasaan antara laki-laki dan perempuan. Perhatiannya tertuju untuk mendorong tatanan sosial yang spesifik bagi perempuan. Disinilah letak pemikirannya yang mengemukakan bahwa sama seperti laki-laki yang membangun rumah, gua, pondok, kota, teori, konsep, bahasa, bahkan perempuan, maka demikian juga perempuan membutuhkan rumah bahasa. Irigaray membuat pembedaan yang vital antara bicara seperti perempuan dan bicara sebagai perempuan, karena bicara sebagai perempuan menyiratkan tidak hanya pemposisian psikologis tetapi juga sosial.

Bicara seperti perempuan, berarti berbicara sebagai perempuan dalam artian yang telah didefinisikan secara maskulin, sedangkan bicara sebagai perempuan adalah berbicara sebagaimana aslinya perempuan, tanpa terkungkung oleh konstruk sosial atas perempuan yang berlaku selama ini. Perempuan harus paham mengenai kondisi ini, agar tidak terus-menerus berada di dalam kekuasaan dominasi maskulin, setidaktidaknya perempuan harus berusaha untuk keluar dari konstruk sosial yang telah dilekatkan tersebut. Jika perempuan mampu keluar dari definisi tersebut maka dengan mudah akan tercipta tatanan sosial yang seimbang antara laki-laki dan perempuan. Kemudian dari pada itu, keluar 
E-ISSN: $2540-9182$

P-ISSN: 2086-3357

dari pendefinisian tersebut berarti keluar dari kungkungan superioritas laki-laki yang selama ini menjadi payung atas kekerasan yang terjadi pada perempuan.

Stereotip gender yang berbeda antara laki-laki dengan perempuan yang berlaku umum di dalam masyarakat sangatlah merekat kuat dalam dasar tatanan sosial. Jika kita telaah dengan apa yang terjadi di masyarakat kita hari ini, pemikiran kedua tokoh di atas adalah relevan bagi penulis, baik Freud yang menganggap perempuan sebagai kealpaan berdasarkan anatomi tubuh sebagaimana yang dikritik oleh Irigaray maupun pemikiran Irigaray sendiri mengenai seksualitas dan hasrat lakilaki dalam bentuk alat kelamin direpresentasikan ke dalam prinsip pengaturan tatanan simbolik kuasa sosial dijalankan. Hal ini tercermin dari tanya jawab yang diadakan oleh BBC Indonesia antara Shena Rindra seorang korban pelecehan seksual yang menjadi survivor dengan netizen melalui sosial media facebook pada hari anti kekerasan terhadap perempuan kemarin ${ }^{11}$, di mana terlihat jelas banyaknya netizen yang menyalahkan korban pelcehan seksual hingga mendapatkan kekerasan secara verbal.

Pada tanya jawab tersebut seorang netizen mengatakan, "Bagiku itu terjadi bukan karena masalah rok mini, tetapi 'isinya' dan isi dalam hati juga pikiran pelaku". Dalam hal ini netizen tersebut memiliki pemikiran yang sama dengan Freud yang memosisikan perempuan

${ }^{11}$ Christine Franciska, Bagaimana Mengakhiri Kekerasan terhadap Perempuan? Diakses dalam http://www.bbc.com/indonesia/majalah/2015/11/151125_trensosial_kekerasan_perempuan (27/11/2015, $14.05 \mathrm{WIB})$. 
sebagai kealpaan yang disebutnya sebagai laki-laki tanpa penis. la menganggap bahwa memiliki vagina adalah masalah. Ini adalah sebuah ironi, bagaimana mungkin memiliki alat kelamin selain penis adalah sebuah kesalahan. Pemikiran seperti ini harus kita luruskan, perbedaan anatomi tubuh perempuan dengan laki-laki adalah sama sekali bukan ukuran siapa yang unggul atau siapa yang sempurna sehingga menyebabkan salah satunya dianggap sebagai sebuah kealpaan. Tuhan telah menciptakan manusia baik laki-laki maupun perempuan dengan bentuk yang sebaik-baiknya.

Selanjutnya ada netizen yang mengatakan "kalau enggak mau diperkosa... , ya jangan mancing orang buat memperkosa". Hal ini sejalan dengan pemikiran Irigaray bahwa seksualitas dan hasrat laki-laki dalam bentuk alat kelamin direpresentasikan ke dalam prinsip pengaturan tatanan simbolik kuasa sosial dijalankan. Dari semua tindak kejahatan, kriminal, atau kekerasan yang terjadi, tidak akan pernah kita mendengar bahwa ada pembenaran untuk melakukan tindakan-tindakan tersebut, namun hal ini berbeda dengan tindak kekerasan seksual bahkan korban adalah pihak yang paling sering disalahkan. Dengan jelas kita dapat membaca pemikiran netizen tersebut di atas bahwa ia membenarkan tindak pelecehan seksual berupa pemerkosaan bahkan yang paling parah adalah menyalahkan korban yang dianggap memancing. Jelas dalam pemahaman kita bahwa tidak ada seorangpun yang dengan sengaja ingin dirinya menjadi korban kekerasan.

Persepsi-persepsi yang menyalahkan korban seperti di atas sebenerarnya sangat lazim terdengar di sekitar kita, salah satu alasannya 
E-ISSN: $2540-9182$

P-ISSN: 2086-3357

adalah karena perempuan yang menjadi korban kekerasan seksual tersebut menggunakan pakaian yang terbuka, bahkan terkadang sesama perempuan yang mengatakan demikian dan penulis sangat tidak setuju dengan hal ini. Persepsi-persepsi yang seperti ini adalah melanggengkan kuasa laki-laki atas perempuan, karena persepsi seperti ini bersumber dari pemikiran laki-laki (yang maskulin) yang memang tidak menganggap perempuan (yang feminin) sebagai subjek melainkan dianggap sebagai objek seksual dan untuk membenarkan pemikiran tersebut maka dibuatlah klaim yang demikian yang menyudutkan korban kekerasan seksual.

Selain itu, persepsi yang demikian sebenarnya tidaklah dapat kita jadikan patokan atau sumber satu-satunya sebagai penyebab kekerasan seksual terhadap perempuan. Data Komnas Perempuan menyebutkan bahwa $60 \%$ kekerasan seksual terjadi di ranah domestik yang pelakunya adalah orang terdekat sang korban. Jika merujuk hal ini maka akar permasalahannya bukan pada cara perempuan berpakaian (hal ini adalah alasan kesekian) melainkan cara pandang laki-laki terhadap perempuan. Terdapat sebuah kasus beberapa tahun silam di daerah Barru, Sulawesi Selatan dimana masyarakat digegerkan oleh seorang perempuan yang melahirkan bayi dengan tubuh yang memiliki lafadz Allah dan perempuan tersebut mengaku anak tersebut lahir tanpa ayah dan ia pernah bermimpi didatangi malaikat yang membawa kabar bahwa ia akan diberi bayi oleh Allah (seperti kisah Mariam dan Nabi Isa A.S). Setelah ditelusuri kebenarannya, ternyata perempuan tersebut adalah korban pemerkosaan yang dilakukan oleh pamannya sendiri dan alasan ia 
melakukan kebohongan mengenai bayinya tersebut adalah karena sang korban merasa harus menutupi aibnya karena ia berasal dari kalangan keluarga yang religius.

\section{Penutup}

Tatanan patriarki mengabsahkan superioritas laki-laki dan inferioritas perempuan yang tidak hanya kita temui pada satu atau dua kelompok masyarakat namun dapat kita temui di seluruh belahan dunia dimana Indonesia adalah salah satunya. Sampai hari ini cacatan Komisi Nasional Anti Kekerasan Terhadap Perempuan menyebutkan setiap 2 jam sekali terdapat 3 perempuan Indonesia yang mengalami kekerasan seksual dan 60\% kasus kekerasan seksual terhadap perempuan terjadi di dalam ranah domestik korban. Bagi Luce Irigaray seksualitas dan hasrat laki-laki dalam bentuk alat kelamin adalah prinsip pengaturan tatanan simbolik dan melalui hal tersebut kuasa sosial dijalankan. Jelas bagi Irigaray, nilai-nilai pencerahan (renaisans) tidak berlaku bagi perempuan. Karena hal tersebut, posisi sosial perempuan hari ini masih termaginalkan, tidak dianggap sebagai subjek melainkan sebagai objek seksual. Perhatiannya tertuju untuk mendorong tatanan sosial yang spesifik bagi perempuan dimana ia membuat pembedaan yang vital antara bicara seperti perempuan dan bicara sebagai perempuan, karena bicara sebagai perempuan menyiratkan tidak hanya pemposisian psikologis tetapi juga sosial. Perempuan harus paham mengenai kondisi ini, agar tidak terus-menerus berada di dalam kekuasaan dominasi maskulin, setidak-tidaknya perempuan harus berusaha untuk keluar dari konstruk sosial yang telah dilekatkan tersebut. 
E-ISSN: $2540-9182$

P-ISSN: 2086-3357

Irigaray berusaha membalikkan tatanan keseimbangan kekuasaan antara laki-laki dengan perempuan sehingga perempuan yang tersubordinatkan dan dominasi maskulin dalam ruang sosial bisa seimbang. Yang perlu kita sadari bahwa membalikkan tatanan keseimbangan tersebut adalah mustahil jika tidak dilakukan secara bersama-sama oleh laki-laki dan perempuan, karena sistem patriarki telah menancapkan kukunya begitu dalam pada tatanan sosial kita. Jika hal ini terjadi, maka juga akan berimbas secara positif pada kasus-kasus tindak kekerasan seksual yang dialami oleh perempuan karena yang perlu kita perbaiki adalah cara pandang laki-laki terhadap perempuan yang berakar dari sistem patriarki.

\section{DAFTAR PUSTAKA}

Brooks, Ann, Posfeminisme dan Cultural Studies: Sebuah Pengantar Paling Komprehensif (terjemahan S. Kunto Adi Wibowo), Yogyakarta: Jalasutra, 2011

Sarup, Madan, Panduan Pengantar Untuk Memahami Postrukturalisme dan Posmodernisme (terjemahan Medhy Aginta Hidayat) Yogyakarta: Jalasutra, 2011

Tong, Rosemarie Putnam, Feminist Thought: Pengantar Paling Komprehensif kepada Arus Utama Pemikiran Feminis (terjemahan Aquarini Priyatna Prabasmoro), Yogyakarta: Jalasutra, 2010

BBC Indonesia. 2015. “Kekerasan Seksual pada Perempuan dan Inferioritas Lakilaki" diakses pada 27/11/2015, 14.17 WIB dari: 
Riska Mutiah

http://www.bbc.com/indonesia/berita_indonesia/2015/11/151125_indo nesia_kekerasan_seksual_inferioritas

Christine Franciska. 2015. “Bagaimana Mengakhiri Kekerasan terhadap Perempuan?" diakses pada 27/11/2015, 14.05 WIB dari: http://www.bbc.com/indonesia/majalah/2015/11/151125_trensosial_ke kerasan_pere mpuan

Tempo.co. 2015. “Korban Kekerasan Pacar seperti Fenomena Gunung Es” diakses pada 27/11/2015,13.50WIB dari: http://gaya.tempo.co/read/news/2015/01/18/205635613/korbankekerasan-pacar-seperti-fenomena-gunung-es 